DOI https://doi.org/10.18551/rjoas.2018-01.21

\title{
VALUE CHAIN ANALYSIS OF COFFEE INDUSTRY: A CASE OF JAVA PREANGER COFFEE IN WEST JAVA, INDONESIA
}

\author{
Perdana Taufik*, Anindita Ratya, Suhartini
}

Faculty of Agriculture, University of Brawijaya, Malang, Indonesia

*E-mail: perdana.taufik@gmail.com

\section{ABSTRACT}

The main objective of this study is to identify Java Preanger coffee chain in Indonesia. Java Preanger was the first coffee from Indonesia exported to Netherland in 1711, known as a cup of Java in international market, and especially in Europe. Identifying the coffee chain processing phase from coffee crop into green bean and coffee as beverage involves many stages, starts with cultivation, harvest, post harvest and processing stage. All these process are key information for farmer to increase their product quality and market access to improve welfare.

\section{KEY WORDS}

Coffee, value chain, West Java, Java preanger.

Coffee is one of the leading commodities that have potential to increase foreign exchange for Indonesia. The superiority and specialty coffee from Indonesia makes Indonesia known as main producer of coffee in the world specialty coffee, which is a coffee that has a characteristic of aroma and uniqueness taste. Specialty coffee from Indonesia already has a large market share in the United States and Europe due to its distinct flavour and aroma compared to other coffees. In addition, specialty coffee has a high competitiveness, indicated by the increasing demand for coffee in the international market. This makes specialty coffee Indonesia become a main commodity for export Based on data from BPS The value and volume of coffee exports in Indonesia are as follows:

Table 1 - Volume and Food On Board price of Coffee export from Indonesia 2010-2014

\begin{tabular}{|c|c|c|}
\hline Year & Volume (Ton) & FOB thousand US \$ \\
\hline 2010 & 433.595 & 814.331 \\
\hline 2011 & 346.493 & 1.036 .671 \\
\hline 2012 & 448.591 & 1.249 .520 \\
\hline 2013 & 534.203 & 1.174 .029 \\
\hline 2014 & 382.750 & 1.030 .716 \\
\hline
\end{tabular}

Source: Statistical Center Body of Indonesia, 2014.

Table 1 above explains that Indonesia is experiencing a decrease in the quantity of coffee export volume in 2014 and the volume of coffee exports tends to fluctuate from year to year. In 2013 Indonesia has the highest export volume value for FOB (food on board in 2012 due to higher coffee prices. Fluctuating coffee export conditions can be attributed by the condition of the area, production and productivity of coffee in Indonesia shows in Table 2.

Table 2 - Area, Production and Productivity of Coffee in Indonesia Year 2011-2015

\begin{tabular}{|l|c|c|c|c|c|}
\hline \multirow{2}{*}{\multicolumn{1}{c|}{ Uraian }} & \multicolumn{5}{|c|}{ Tahun } \\
\cline { 2 - 6 } & 2011 & 2012 & 2013 & 2014 & 2015 \\
\hline Luas Areal (Ha) & 1.233 .699 & 1.235 .289 & 1.241 .836 & 1.230 .495 & 1.233 .227 \\
\hline Produksi (Ton) & 638.647 & 691.163 & 675.881 & 644.592 & 665.256 \\
\hline Produktivitas $(\mathrm{Kg} / \mathrm{Ha})$ & 702 & 745 & 739 & 716 & 721 \\
\hline
\end{tabular}

Source: Directorate General of Plantation, 2015 
Value chain analysis was a method to series of activities undertaken to produce a product ranging from conceptual to marketing activities, each of which activities that added value to the final product ( ACIAR, 2012). Measurement of the value chain to be important in explaining activities ranging from the supply of raw materials, processing, to distribution to the consumer. Agro-industrial processing in this case have an important role to increase the value added of agricultural products into a final product that is ready for trading. This Concept analysis has been used to study political economy framework and international trade known as Global Value Chain (Gereffi, 1994; Kaplinsky, 2000, 2004).

The main objection of a value chain is to produce value added products or services for a market destination, by transforming resources and by the use of infrastructures within the potential and constraints of its institutional environment. Therefore, constraints for value chain development are in our view related to market access (local, regional, international) and market orientation (Grunert et al. 2005), available resources and physical infrastructures (Porter 1990: factor conditions) and institutions (regulative, cognitive and normative; Scott 1995).

Coffee crops produce cherry as the output product and transforming into green bean and becoming roasted beans after several stage of processing. The main product coffee was sold in green bean or roasted bean depends on the market request. The latest trend of the coffee market focussing on quality competition requires reliable supply chain relationships and contractual procedures for improving farm management procedures and product handling processes (Petkova, 2006). Among the various potential crops for commercialization, coffee Becoming as a likely agro-enterprise with great potential to provide farm employment and income generation opportunities in the mid hills of Nepal (CoPP, 2007). Coffee was a annual crops that harvesting after 3-4 years and cherry was the main product from crops. Harvesting coffee in Kenya always using manual labours to achieve cherry that already ripe, it needs a lot of labour and expensive (Chege, 2012). In Indonesia one of the potential coffees was Java preanger which have unique taste and aroma, which cultivate in west java region.

Coffee is processed either by wet method to produce parchment coffee or by dry method to obtain cherry coffee, In Nepal; dry processing was predominantly practiced in the past. But nowadays, this method has gradually been replaced by wet processing method. Wet method has also becoming more popular and been introduced for export of green beans (Deoju and Manandhar, 2004). The processing method is important for contributing the aroma and flavour in coffee cup quality. Therefore, the quality of coffee is dependent on careful postharvest processing. In primary coffee processing level which starts after harvesting up to drying of parchment, the fermentation of parchment after depulping is the most important stage for maintaining the quality of coffee. If fermentation lasts long, microbial inhibition takes place resulting to pungent flavour and stinker beans and ultimately affects cup quality. (Raghu, 2011)

In this paper we analyze the production chain of coffee based on the stage of production from input facilities, support, cultivation, harvesting, post harvesting, processing and marketing in order to understand where were the value is added in each stage. This paper also will explain the actor that contributed for increase value in Java preanger coffee and compares the value of benefits that received in each actor especially between farmer and middlemen.

\section{METHODS OF RESEARCH}

Value chain analysis is tools to show competitive advantage and showing the potential and the source of advantage. By designing activities and analyse the advantage factor from all the activities (Porter, 1985) value chain constructing the activities from the beginning until final product. In coffee production it's from cherry until coffee beverages as a final product, including all the actor that contribute in value chain from farmer until consumer. There always a linkage between the actor of chain, the linkages will show how efficient the production of these product. By systematic categorization of activities and identify the value that should be 
upgrade and improve the product competitiveness. The activity in chain will divided into two activity, Primary and support activity. Primary activity directly involves in transforming product physically and transfer it into customer with after sales service, Support Activity role is to give the input by giving technology and human resource development. Primary activity consists of inbound logistic, operation; outbond logistics, marketing, selling and service. And in support activity consist of procurement, innovation with technology, human resource management and infrastructure.

Value chain analysis was methode to increase potential and competitive advantage, with identifying challenge in market and involves farmers as the main producer, it will upgrading the chain as a whole systemic benefits. In this paper we examine the chain activities that go in domestic market especially in coffee roastery and coffee shop in Indonesia. Indonesia coffee industry having a specific pattern of market, nowadays there was increasing demanrd in single origin coffee. The chain of coffee was including few actors like farmersntc, cooperative, supplier, roaster, trader and coffee shop. It needs inter organisational analysis to see the value (price) in each stage in the chain. Identifying the price can explain us the value added in each stage of chain. We also discuss some economic and social impact between the farmer and the trader in coffee chain.

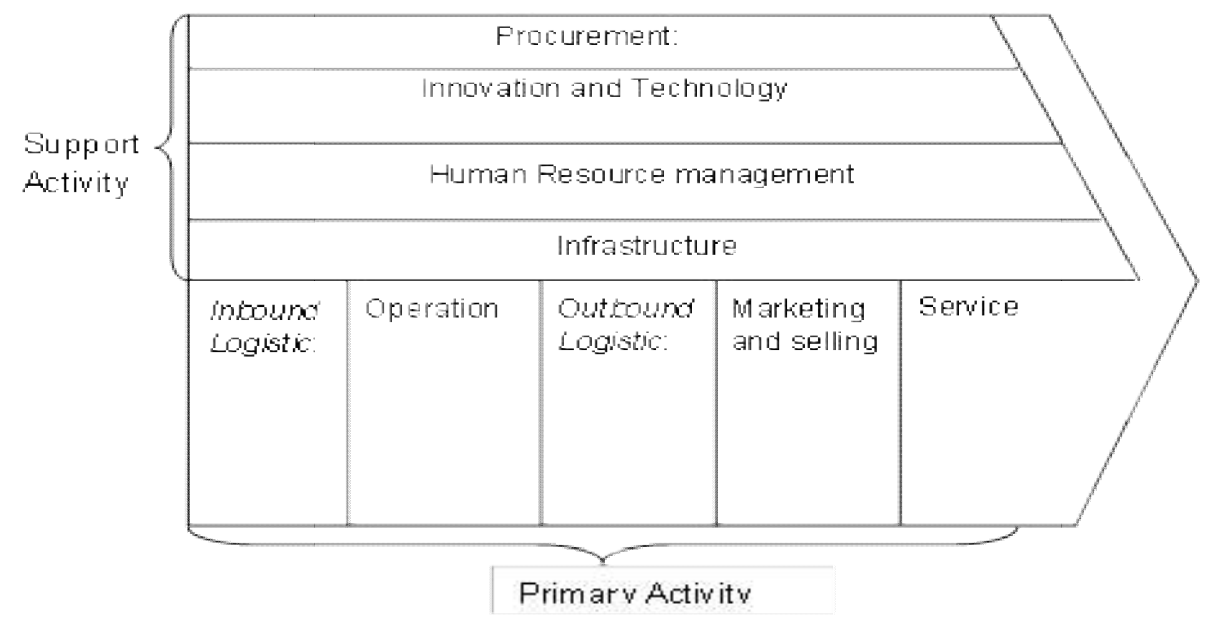

Figure 1 - Value Chain Activity (Source: Porter, 1985)

The primary activities selected to a cooperative that has a prior knowledge to coffee chain and its confirmed nya primary and secondary data sources. Mixed data sources were used for this study. Interviewer were choose by their knowledge and expertise at different stage of coffee value chain. For Farmer respondents using sampling techniques saturated or census of all population is used as a sample. The another respondents of this papar was coffee supplier, roastery and coffee consumer. Determination of the respondents involved in the value chain of Java Preanger Coffee done by snowball sampling is based on the value chain of information flow from the producer to the consumer. While the determination of the final consumer respondents to the analysis of critical success factors using the minimum limit of sampling as many as 30 respondents (Roscoe in sekaran, 1992). Methods of data analysis using Porter framework analysis (Porter 1985) and mapping analysis (Kaplinsky and Morris, 2001).

Interviews were doing by person to person and for customer, it conducte.d by email questionnaire. The secondary data and question was obtain from all interviewer that were specific to their area of specialties. Focusinh issue to upgrading management of famer in coffee chain. These data also came from visits to sites in west java, Indonesia where arabica java preanger was produced into final form and it organized only by the farmer cooperative union with their own simple technology. 


\section{RESULTS AND DISCUSSION}

This value chain analysis was data that gathered in time - June 2017. In tis part we give the detail informatioan about value added at each stage and identify the actor of coffee chain in Indonesia. We will summarize the prices value in each actors and stage to give more explanation about the value chain of this commodities.

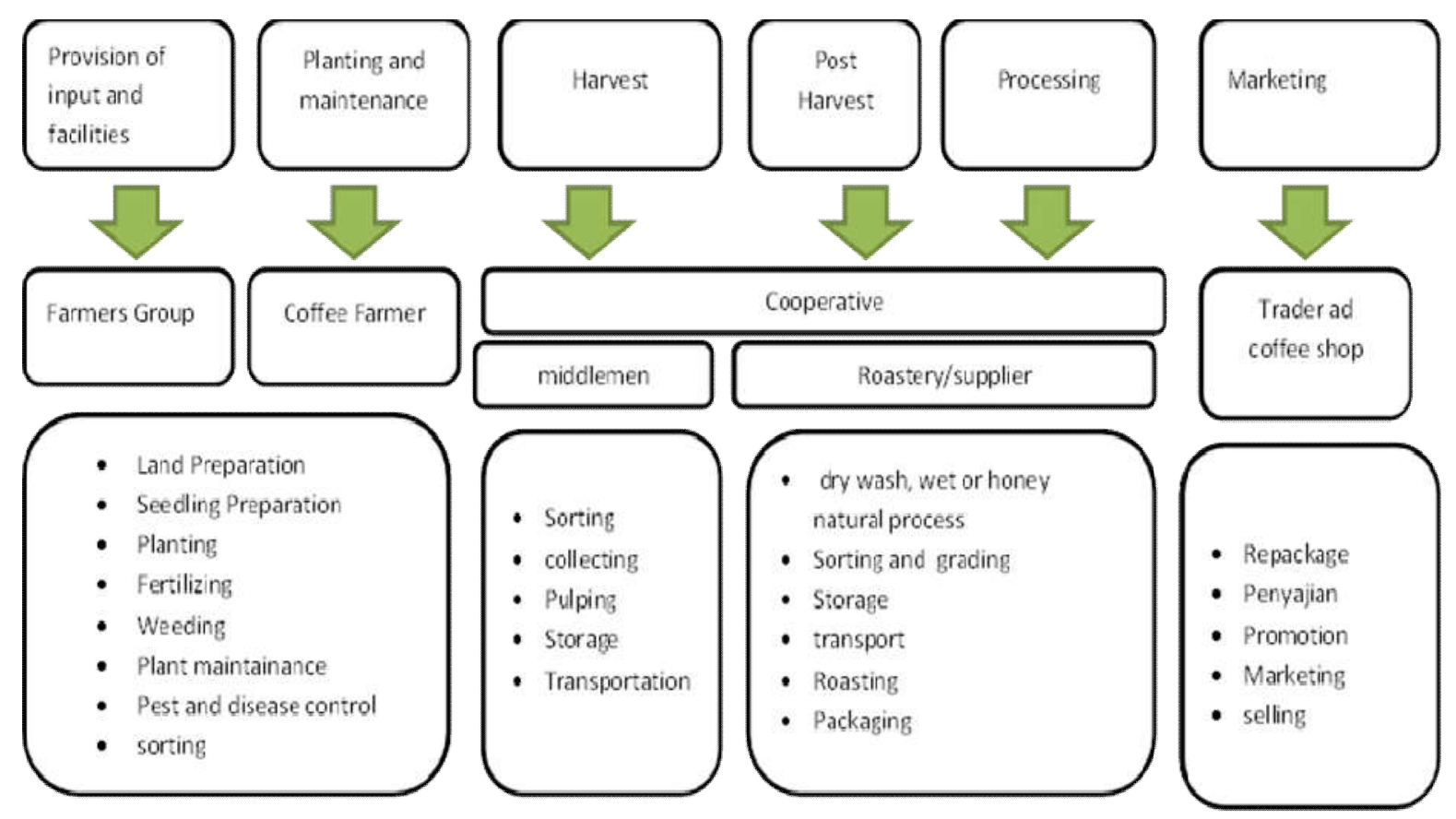

Figure 2 - Mapping Specifific activity of Coffee Chain

In Figure 2 that showes us the process of coffee each stage in different actors with their activity. farmer group collaborate wit farmer to make sure the input and facilities for coffee cultivation. The main parts of these chain was Provision input and facilities, planting and maintenance, harvest, post havest, processing and marketing.

Actors in Coffee Chain. The actors in coffee chain consist of Farmer, Cooperative, Middlemen, Roastery, trader or coffee shop. The role of each actor will explained in detail below:

1. Farmer. Farmer as a main actor in this chain was a producer of coffee, their role was to preparing the seeds, cultivate crops, maintaining and protect them from pest and disease and harvesting the cherry from the crops. Majority of the farmer in west java was a indigenous society at that region. They learn coffee from their ancestors, Likely its more than 30 years. In production process there was few stage, consist of seedling, cultivation, fertilizing, pest and disease control, harvest and post harvest. Most of harvest product will be distribute to a middle men called "tengkulak". Or Cooperative union. Most of the agreement was informal or not using contract. Just an agreement. In term of payment they using cash or phased payment.

2. Cooperative Union. Cooperatve was a organisation that bought cherry from farmer. Cooperatives and private investors offer extension services and sometimes credit to coffee farmers. Farmers who sell parchment coffee do not receive these benefits. These benefits are predicted to have a strong effect in consumption smoothing and reducing poverty (Badiane et al., 1999). Coopertative inthis paper have a vital role in coffee chain, becausse their have a big part in post harvesting, processing and marketing. In this stage we will analyse more detail abaout the procedure and the activity that occurs in this specific chain.

3. Middlemen. Collective trader or middlemen have role to collecting the coffee cherry from farmer, ussualy they buy it freshly and not processing. The price was determined by the trader based on quantity and cherry condition. In west java especially in cilengkrang region 
the price of cherry was about Rp 7000 per kilogram. the collecctive trader will gatherng all the cherry and will be processin into another stage and sell them to bigger suplier or Factory. The term of payment divided into two method, first was cash on the spot or they paid the coffee chery on the farm. Secondly was installment payment, they paid in process or not cash it could take 3-4 month. In this stage all the transportation cost was borne by the trader. They were came directly to the farm to get their cherry.

4. Supllier. Supplier was a main trader that collect their product from collective trader. They collect the product and processing them into final product and sell them in market. They have their own roasting machine with big capacity and packaging machine. They have another role to be exporters but in term of java preanger coffee still in development to export. The main activity from supplier of java preanger coffee was distributed the product to the other region like sumatra, java, sulawesi and bali with their own brand.

5. Roastery and coffee shop. Roastery and coffee shop was relatiely new actor in coffee chain in indonesia. Usually the domestic market was dominated with instan coffee from big company but nowadays as the third wave coffee also came in indonesia, the consumer wants more about coffee and they choose to appreciate single origin coffee with different techinique of presentation. Roastery have role to roast the green bean from farmer or collective trader, after the roast process was packaging, they would package the product with their own brand and sell it to coffee shop or consumer. Roasting type in coffee consist of three types, light, dark and medium roast. Coffee shop having role to present the roast coffe to be the beverages that ready to consume. Different technique of coffee presentation become basic requirement in coffee shop, Barista was the people that create coffee with the special tehnique. They learn about processing and presentation techinique manual brew with vietnam drip, V60, Turkish, and espresso machine with their latte, machiato, cappucino was a differen kind of product made by barista. In this phase the price of coffee higher than another phase. It become premium quality beverages. Java preanger was one of the premium single origin coffee that have their own consumer. The sweet taste with nutty and caramel become the unique taste from Java Preanger coffee. The consumer usually order with maunual brew option to taste it deeply.

6. Consumer. Consumer of java prenager coffee was different, their targeted a middle until higher income people, usually was office employee or college student. The price of java preanger coffee higher than another coffee because its had a high quality and unique taste. The preference of java preaner consumer was to enjoy the taste and scent. These two factors was key point of java preanger competitivenes in market.

Main Activities in Coffee Chain. Main activity in chain was an activities that included the physical transformation of the product and its sales, continued by product distribution to the consumer and after sales assistance. The categories in the primary activities are as follows: Inbound logistics, operations, outbound logistics, marketing and sales and servicing (Porter, 1994). It will be explained in detail the activities of Coffee Industry in West Java.

a. Inbound Logistics. Inbound logistics was the integration of elements in the business that includes the activities of receiving, storing and distributing inputs of raw materials used in production. In the coffee industries, this process starts from the provision of facilities and infrastructure in the cultivation of coffee such as land preparation, certified seed preparation, and preparation of fertilizers and optical handlers. Usually these inputs are obtained from certified farmers or government grants. In the provision of seeds other than derived from government assistance the farmers also do the nursery process directly. Seeds are certified to have good resilience and production quality.

b. Operation. Operation is an activity that changes physical input into output The first activity done in coffee making is grading and sorting of coffee cherry. Cherry coffee used is a red color because it has a good maturity and good quality of this harvest process known as red picking. Another criterion of good cherry is the level of hardness and percentage of sugar content other than that the coffee fruit has a soft texture, slimy and slightly watery. Furthermore, it will be done one of the coffee processing process that is natural process that begins with drying, grinding, and sorting of coffee beans and grading based on seed size. Other types of process are honey, dry and wet process which will be described more clearly 
in the table below. Once in the process of being green bean with various processes will be done roasting and will proceed by checking the quality of flavor, aroma and color through the process of cupping.

c. Outbond logistics. Outbond logistics are all activities in the collection, storage (storage) and distribution of output. The process of outbound logistic in the coffee business includes the preparation of stock and demand of coffee beans in several types of demand from the demand of natural types, honey, wet and dry process and demand in the form of green bean or roasting bean and coffee demand in ready-to-eat packaging will be distributed to coffee business actors such as wholesalers and coffee shops. In the distribution process the majority of coffee bean buyers come to the coffee collection location to make purchases and quality coffee beans, in addition to being picked up by the buyer there is a shipment of coffee beans to some fixed consumers in the coffee shop even though the amount is not much.

d Sales and marketing. Subsequent activities are marketing and sales that begin by disseminating information and promotions related to products to be marketed. Promotion is done in the form of providing information related to the superiority of the product and its uniqueness through the media information or the manufacture of outlets or coffee shops to market coffee products directly.

In the process of brand or packaging marketing becomes an important thing in attracting consumers to buy these coffee products. The completeness of the information in the packaging becomes one of the important things in the process of marketing and selling in the coffee product, the name of the coffee, the type and processing done and the date of roasting becomes one of the examples of information contained in the packaging. In the sales process is done in the form of informal and sold directly with payment in full or gradually. The products sold have different prices depending on the quantity and quality purchased by consumers.

e. Service. Subsequent activities are services aimed at maintaining and increasing the value of the product. Service activities undertaken in the coffee business is the delivery of coffee beans to consumers remain in accordance with the demand. In addition to these activities to check the quality of coffee beans when in the consumer is also one of the forms of service performed cooperative producers happy giri. Performing different types of coffee innovations through differentiation of coffee products such as coffee, coffee, coffee and candied coffee is a form of improving product quality and meeting market needs.

Supporting Activities in Coffee Chain. Support activities within the porter value framework have an objective to support the primary activity. One of its forms is technology, technology development, human resource management and infrastructure development (Porter, 1994).

a. Procurement. The activity of providing inputs is part of procurement, purchasing certified coffee seeds, fertilizers, and pesticides as well as purchasing huller machines, drying and roasting machines, office equipment and coffee outet needs such as banners, promotional banners and others as part of activities in the coffee chain.

b. Technology Development. Technology development is one of the activities that support inbound logistics which will be related in transformation of physical transformation of input into output. In this research, cherry transform into a cup of coffee that ready to consume. The technology used in coffee business have several types starting from post harvest technology such as pulping machine, huller machine, and drying machine followed by processing technology such as roasting machine and grinder. Coffee bussines also required packing machine for packaging. in addition to tools and machinery in the production needed also some tools in coffee. To make a good coffe beverages its required various types of tools such as espresso machine, frenchpress, v60, and aero press.

c. Human Resource Management. Management especially in human resources becomes very important. Human resourcse in cooperatives were coffee farmers. stages of HR management in the cooperative was recruitment of new members, training, regular meetings and distribution of in). Registered members must pass through the selection stage of the cooperative board. the criteria needed are coffee farmers who are already producing 
and lived in kecamatan cilengkrang, and willing to follow the membersip rule. Share benefit system motivates farmers to produce with good quantity and quality because it will provide additional income. Members of cooperatives also have a role in maintaining the quantity of production and quality in the post-harvest and processing process.

d. Company infrastructure. Infrastructure is a supporting activity in a company in a cooperative some existing infrastructure is a nursery, a place of fermentation of coffee beans, coffee wash, drying and huller machine room, dryer. and roasting house and there is a coffee promotion outlet as a place to display coffee products and various derivatives of other products.

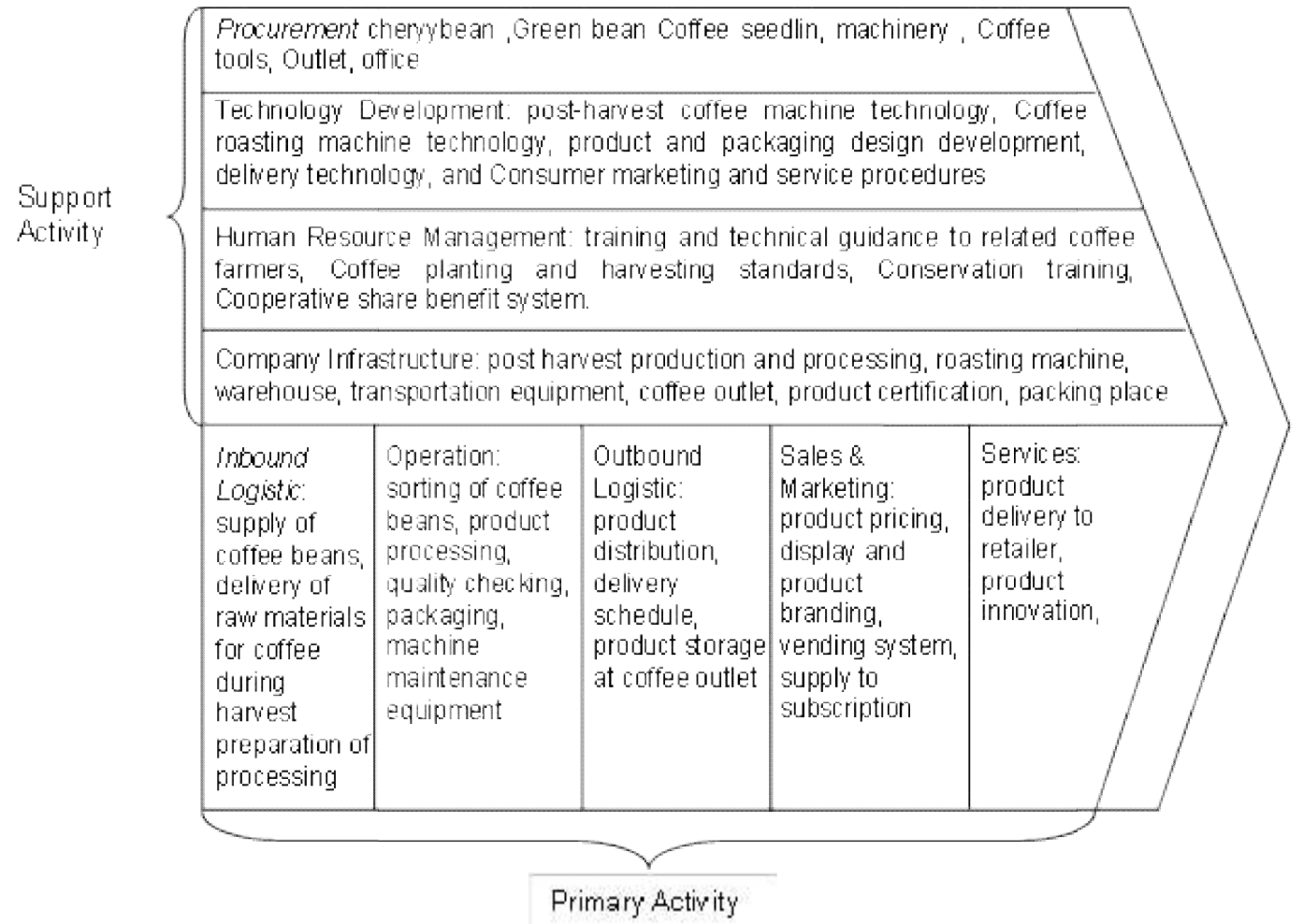

Figure 3 - Value Chain Framework of coffee

Marketing margins are used to determine the benefits that each value chain actor receives. Definition Marketing margins are the price differences that occur between value chain actors. Marketing margin method begins by calculating marketing margins, share prices at farm level, share prices at cooperative, retail and wholesale, and roaster levels. The division between cost, revenue, net income, and margin aims to look at the financial position of each offender against another. The following is a margin calculation table and price share of each value chain actor that can be seen on table 2 .

Table 2 - Value added price at each stage of coffee chain in $1 \mathrm{~kg}$ of coffee

\begin{tabular}{|c|c|c|c|c|c|}
\hline \multirow{2}{*}{ Actors } & \multicolumn{3}{|c|}{ Benefits } & \multicolumn{2}{c|}{ Margin } \\
\cline { 2 - 6 } & Price & Benefits & Benefit / unit & marjin/unit & $\%$ final price \\
\hline Farmers & Rp8.000 & Rp2.000 & $1,40 \%$ & Rp8.000 & $3,40 \%$ \\
\hline Cooperative & Rp20.000 & Rp4.000 & $2,60 \%$ & Rp12.000 & $5,10 \%$ \\
\hline Trader & Rp80.000 & Rp57.000 & $32 \%$ & Rp68.000 & $29 \%$ \\
\hline Roastery & Rp235.000 & Rp115.000 & $64 \%$ & Rp147.000 & $62,50 \%$ \\
\hline \multicolumn{3}{|c|}{ Total } & Rp235.000 & $100 \%$ \\
\hline
\end{tabular}

The figures on table 2 identify the margin price in each actors. Farmer contribute 3, 4\% in final price of coffee and roastery give $62,50 \%$ of final prices. The initial cost of coffee in roastery are higher than another phase, because they need capital for buying roast machine, 
sortation machine and packaging machine. The roaster need to get a certification of roastery skill. For farmer especially in west java regionget their seddling from goverment support. and they bought another tools and ingredients like fertilizer, pest control, watering can and others. Cooperative have different roles in the stage of coffee. They have the secon higher in term of cost because of post harvesting process also need machinery like milling and pulping machine.

\section{CONCLUSION}

The study has shown that the quality Java Preanger Coffee determined by good seedling, cultivation stage post harvesting and roasting. Post harvesting and roasting stage can added value of coffee to enter domestic and international market. Actors in coffe chain consist of farmerof For farmer there is room for upgrading the quality to increase the margin and benefits from coffee. Fitter and Kaplinsky (2001) showed, increasing differentiation of coffee prices at the retail or specialty shop outlets does not translate into increasing variance in prices paid at the farm gate. This means that farmer should do the processing until final product to achieve higher price at the farm gate. We also identify opportunities in term of create product besides coffee like Coffee leaf tea and Cherry snacks from the wastage of coffee. It will increase the income of farmer besides the main product. Recommendation for this research was to make a further value chain analysis about 1 or 2 year to see the dynamics change of value added in coffee chain. Including wider area of research likes exp mar also makes further analysis about the relation beetween producer, government and trader and their role to improve coffee chain in Indonesia.

\section{REFERENCES}

1. Australian Center for International Agricultural Research. (2012). Value Chain Pro Poor Development: a Practical Book. Australia.

2. Badiane, O., and M. Kherallah (1999). 'Market Liberalization and the Poor'. Quarterly Journal of International Agriculture, 38(4): 341-58.

3. Chege J. (2012) Value Addition in Coffee Industry in Kenya: Lessons from Cut Flower Sector Kenya Institute for Public Policy Research and Analysis (KIPPRA), Nairobi, Kenya ICBE-RF Research Report No. 21/12.

4. CoPP (2007) Coffee Promotion Programme Annual Report 2006. Helvetas Nepal, Bakhundole, Lalitpur, Nepal.

5. Deoju LN, Manandhar S (2004) An Overview of Specialty Coffee. Tea and Coffee Development Section, Kirtipur, Kathmandu, Nepal.

6. Fitter, R. and R. Kaplinsky, (2001), "Who gains from product rents as the coffee market becomes more differentiated? A value chain analysis", IDS Bulletin Special Issue on The Value of Value Chains, Vol. 32, No. 3, pp. 69-82.

7. Gereffi, G., J. Humphrey, and T. Sturgeon.( 2004). "The Governance of Global Value Chains" Review of International Political Economy.

8. Grunert, K. G. (2006). How changes in consumer behaviour and retailing affect competencerequirements for food producers and processors. Economia Agraria y RecursosNaturales, 6(11).

9. Kaplinsky, R., and M. Morris, (2001). A handbook for value chain research. Ottawa, Canada, International Development Research Center. 